\title{
Reproductive cycle of Loligo sanpaulensis (Cephalopoda: Loliginidae) in the Cabo Frio region, Brazil
}

\author{
P. A. S. Costa, F. C. Fernandes \\ Instituto de Estudos do Mar Alte Paulo Moreira (IEAPM), Rua Kioto, 253 Arraial do Cabo, 28930-000 Rio de Janeiro, Brazil
}

\begin{abstract}
Gonadal index and maturity stages of the Brazilian squid Loligo sanpaulensis were analysed on a monthly basis. Squid were caught in coastal waters off the Cabo Frio region, Brazil, between 1987 and 1988 at depths ranging from 30 to $60 \mathrm{~m}$ using an otter trawl with $10 \mathrm{~m}$ footrope and $45 \mathrm{~mm}$ cod-end mesh size. Field data analysis showed that development of the nidamental gland and testis was closely related $(r>0.9)$ to body size and maturity stage in the population. Mature individuals are recruited into the population twice a year. Size at first maturity was estimated to be 50 to $55 \mathrm{~mm}$ mantle length (ML) for males and 55 to $60 \mathrm{~mm}$ ML for females. Indirect evidence suggests that the final phases of the maturity process in females occur abruptly at some point after that size, and that recruitment of juveniles follows spawning and subsequent mortality or emigration of adults from the sampling area. Spawning is likely to take place in late summer and late winter
\end{abstract}

\section{INTRODUCTION}

Basic information on maturation and size at maturity is fragmentary for many cephalopods, especially for those living in non-seasonal environments. Studies on cephalopod reproduction have indicated that the physiological and behavioural changes associated with maturation (gonad enlargement, slowing and cessation of somatic growth and loss of feeding behaviourj are not reversed after breeding. Thus, the general opinion is that cephalopods, with few exceptions, normally produce only one batch of offspring in their lifetime and die after breeding (Boyle 1990). This reproductive pattern is called semelparity (Cole 1954).

Onset of maturity is seasonal in many temperate species, and in most neritic and oceanic squid, maturity is associated with a cycle of migration into coastal waters or is related to currents, temperature and food supply in the water. Conversely, little is known of the spawning seasonality of tropical and subtropical squid and cuttlefish (Mangold 1987). In several loliginids mature females and eggs are found year-round. In the Guif of
Mexico Loligo pealei spawns throughout the year (Hixon 1980). Sepioteuthis sepioidea in the western tropical Atlantic and $S$. lessoniana in the western Pacific also spawn year-round (Choe 1966, LaRoe 1967). However, the greater abundance of recruits during certain periods of the year suggests that some seasonality exists.

This paper summarizes the available data on reproductive biology of Loligo sanpaulensis in southern Brazil, from Rio de Janeiro $\left(23^{\circ} \mathrm{S}\right)$ to Rio Grande do Sul $\left(34^{\circ} \mathrm{S}\right)$. Gonadal index, maturity stages and sex composition are presented. The relationship between recruitment patterns and hydrographic conditions is discussed.

\section{MATERIALS AND METHODS}

Monthly samples of Loligo sanpaulensis were collected in the Cabo Frio region, central-southern Brazilian littoral zone $\left(23^{\circ} \mathrm{S}, 42^{\circ} \mathrm{W}\right)$, from January 1987 to October 1988. During this period, squids from 11 to 
$118 \mathrm{~mm}$ dorsal mantle length (ML) were caught in 57 of 71 trawls with a $10 \mathrm{~m}$ footrope net towed at depths ranging from 30 to $60 \mathrm{~m}$ (Fig. 1)

The specimens were fixed in $10 \%$ formalin and preserved in $70 \%$ ethanol. The ML of every specimen from each month was measured to the nearest $\mathrm{mm}$ with vernier callipers. Sex was determined and the ganads were exposed by making a longitudinal incision in the ventral side of the mantle. Each squid was assigned a maturity stage on a scale of 0 to III, after Juanicó (1983): 0, juvenile (no gonads); I, immature; II, maturing; III, mature. This scale is a measure of sexual maturity for females, based on the relative size of the ovary, nidamental glands and oviductal glands as well as the presence and colour of free ova in the ovary

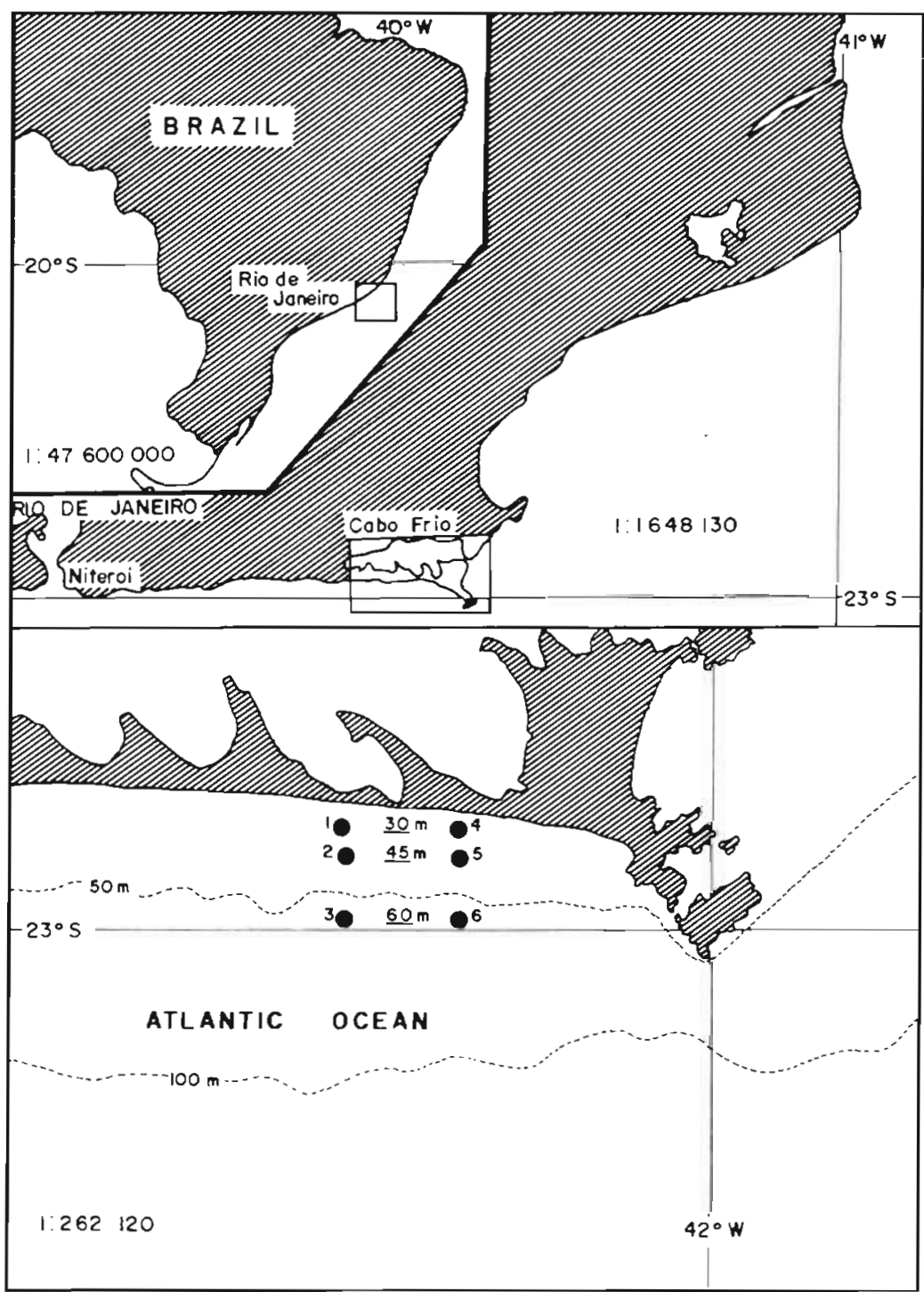

Fig. 1 The Cabo Frio region showing the location of trawls and stations for hydrological samples (1 to 6 ) and oviducts, and for males, on the relative size of the testis and the presence of spermatophores in the spermatophoric sac.

In females, the length of the nidamental glands (NGL) and ovary (OL) was measured and the ovary weighed (wet weight of ovary plus oviductal ova). In males, testis length (TL) and testis weight (TW) were recorded. All weights were rounded to the nearest $0.1 \mathrm{~g}$ and measurements to the nearest $\mathrm{mm}$. In adition to the maturity stages qualitatively determined, several maturity indices previously described in other studies (Hayashi 1970, Durward et al. 1979) were calculated. Those which relate the length of the nidamental glands (NGI) and testis (TLI) to mantle length showed the highest correlations. Therefore, these indices were used in this study as quantitative indicators of sexual maturity and expressed numerically as a function of mantle lengthi NGI = NGL/ML in females and TLI $=$ TL/ML in males.

\section{RESULTS}

\section{Maturity stages}

Gonads from 1138 specimens (340 males, 365 females, 433 juveniles) of Loligo sanpaulensis were examined. Table 1 shows the variations and ranges of weight and length of the reproductive organs among the different maturity stages for males and females.

The overall sex ratio $(1: 1.07$ males: females) did not significantly differ from parity. Females ranged from 27 to $103 \mathrm{~mm} \mathrm{ML}$ and 1.1 to $46.9 \mathrm{~g}$ total weight. Based on the presence of mature eggs in the ovary and oviducts, the smallest sexually mature female was $50 \mathrm{~mm} \mathrm{ML}$, and the largest immature female was $71 \mathrm{~mm}$ ML. The size distribution of mature females in the population based on data pooled throughout the year is shown in Table 2 .

All mature females had relatively large, opaque and white nidamental glands. In this group, nidamental gland length ranged from 14.0 to $53.0 \%$ of mantle length. Considering all females, the length of the nidamental glands was strongly correlated ( $\mathrm{r}=$ 0.95) with ovary length (Fig. 2), and when related to mantle length could be 
Table 1. Loligo sanpaulensis. Variations and ranges of welght (g) and length (mm) among various maturity stages of squid sampled between January 1987 and October 1988 in the Cabo Frio region, SE Brazil

\begin{tabular}{|lccc|}
\hline & Immature & Maturing & Mature \\
\hline Males & $\mathrm{n}=160$ & $\mathrm{n}=90$ & $\mathrm{n}=90$ \\
Total weight & $0.6-10.7$ & $3.2-15.4$ & $5.4-43.5$ \\
Dorsal mantle length & $20-61$ & $41-81$ & $48-118$ \\
Testis weight & $<0.1$ & $0.1-0.2$ & $0.1-2.3$ \\
Testis length & $3-17$ & $9-28$ & $13-51$ \\
Females & $\mathrm{n}=233$ & $\mathrm{n}=74$ & $\mathrm{n}=58$ \\
Total weight & $1.1-13.4$ & $5.9-21.3$ & $6.2-46.9$ \\
Dorsal mantle length & $27-71$ & $49-76$ & $50-103$ \\
Ovary weight & $0.1-0.2$ & $0.1-1.1$ & $0.1-5.3$ \\
Ovary length & $4-21$ & $9-32$ & $11-53$ \\
Nidamental gland length & $1-10$ & $5-30$ & $7-35$ \\
\hline
\end{tabular}

used as a maturity index. In immature females, the glands were colourless and smaller.

The relationship between nidamental gland length and mantle length is shown in Fig. 3 for females classified by maturity stages. There was considerable scatter, mainly after $60 \mathrm{~mm}$ ML. This suggests that the final phases of the maturity process occur abruptly at some point after that size, irrespective of somatic growth. The overlap maturation stages is considered to result from the use of an oversimplified maturity scale fonly 3 stages), which fails to distinguish the latest stages of maturation. However, the use of such a scale makes it possible to compare the maturation process in populations of squid from different areas.

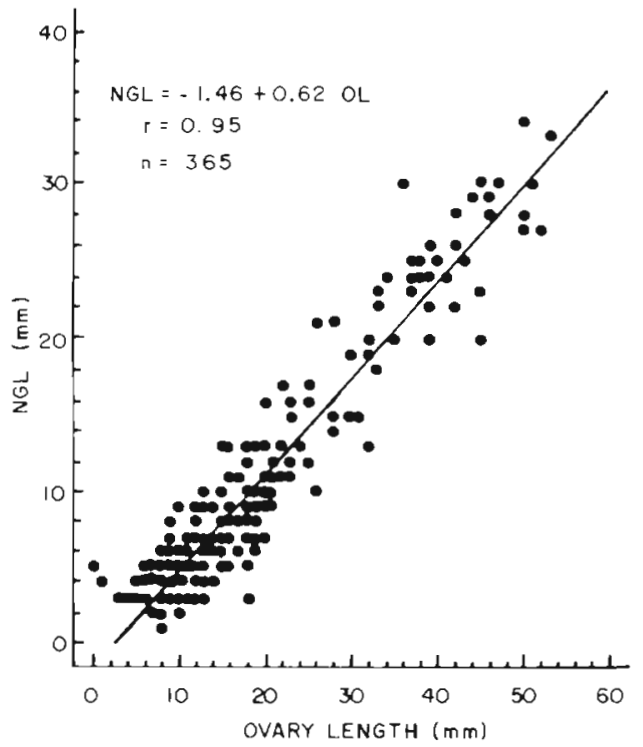

Fig. 2. Loligo sanpaulensis. Relationship between nidamental gland length and ovary length from data obtained during 1987 and 1988

The males ranged from 20 to $118 \mathrm{~mm} \mathrm{ML}$ and 0.6 to $43.5 \mathrm{~g}$ total weight. Sex could be determined in squid $>20 \mathrm{~mm}$ ML. The smallest mature male measured $48 \mathrm{~mm} \mathrm{ML}$, and the largest immature male $65 \mathrm{~mm} \mathrm{ML}$. Testis length increased with body size ranging from 27.0 to $44.7 \%$ of mantle length. Testis length displayed a linear relationship with body size (Fig. 4), showing a consistent tendency to increase in length with advancing maturity.

Table 2. Loligo sanpaulensis. Frequency of immature (Stage I) vs mature (Stages II and III) squid sampled between 1987 and 1988 in the Cabo Frio region $\left(23^{\circ}\right.$ S), SE Brazil. \% Mat.: percent mature individuals; TLI, NGI: average maturity index

\begin{tabular}{|c|c|c|c|c|c|c|c|c|c|c|c|c|}
\hline \multirow{2}{*}{$\begin{array}{l}\text { ML, class } \\
\text { midpoint (mm) }\end{array}$} & \multicolumn{6}{|c|}{ —_ Males - _ _. - } & \multicolumn{6}{|c|}{ - Females - } \\
\hline & 1 & 11 & III & $\%$ Mat. & TLI & $\mathrm{SD}$ & 1 & Il & III & $\%$ Mat. & NGI & SD \\
\hline 15 & & & & & & & & & & & & \\
\hline 20 & 1 & & & & 1.84 & & & & & & & \\
\hline 25 & 3 & & & & 1.68 & 0.34 & 15 & & & & 0.88 & 0.25 \\
\hline 30 & 16 & & & & 2.21 & 0.35 & 17 & & & & 0.94 & 0.27 \\
\hline 35 & 16 & & & & 2.02 & 0.57 & 52 & & & & 0.97 & 0.24 \\
\hline 40 & 47 & & & & 2.41 & 0.51 & 59 & & & & 0.92 & 0.19 \\
\hline 45 & 36 & 8 & & 18.2 & 2.59 & 0.67 & 27 & 2 & 1 & 10.0 & 0.99 & 0.39 \\
\hline 50 & 20 & 14 & 4 & 47.3 & 2.67 & 0.40 & 28 & 7 & 2 & 24.3 & 1.18 & 0.62 \\
\hline 55 & 12 & 12 & 5 & 58.6 & 2.72 & 0.44 & 21 & 9 & & 27.6 & 1.25 & 0.29 \\
\hline 60 & 7 & 24 & 8 & 82.0 & 2.85 & 0.54 & 9 & 22 & 3 & 73.5 & 1.51 & 0.61 \\
\hline 65 & 2 & 17 & 8 & 92.6 & 2.92 & 0.48 & 4 & 13 & 3 & 80.0 & 1.80 & 0.95 \\
\hline 70 & & 12 & 16 & 100.0 & 3.05 & 0.43 & 1 & 18 & 9 & 96.4 & 2.13 & 0.92 \\
\hline 75 & & 1 & 12 & 100.0 & 3.45 & 0.34 & & 3 & 11 & 100.0 & 2.38 & 0.62 \\
\hline 80 & & 1 & 19 & 100.0 & 3.56 & 0.40 & & & 12 & 100.0 & 2.95 & 0.30 \\
\hline 85 & & 1 & 6 & 100.0 & 3.41 & 0.26 & & & 5 & 100.0 & 3.29 & 0.26 \\
\hline 90 & & & 6 & 100.0 & 3.40 & 0.33 & & & 8 & 100.0 & 3.14 & 0.31 \\
\hline 95 & & & 4 & 100.0 & 3.43 & 0.30 & & & 3 & 100.0 & 2.77 & 0.13 \\
\hline$>95$ & & & 2 & 100.0 & 3.73 & 0.39 & & & 1 & 100.0 & 3.35 & \\
\hline
\end{tabular}




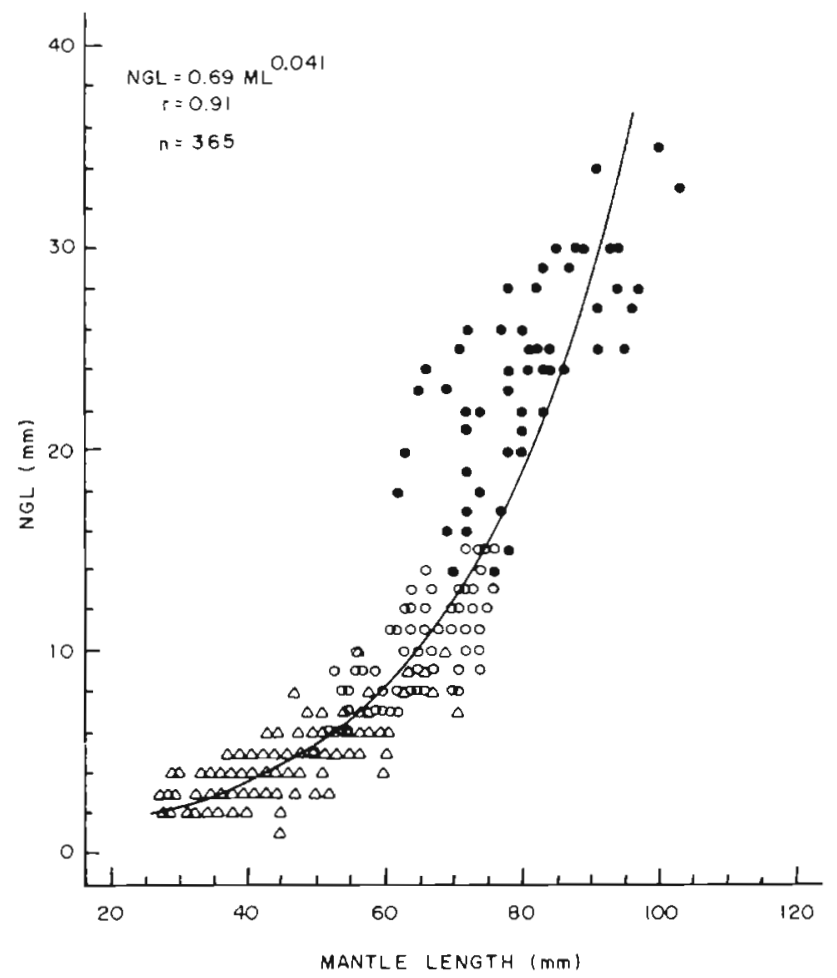

Fig. 3. Loligo sanpaulensis. Relationship of nidamental gland length and mantle length for females classified according to maturity stages. $(\Delta)$ Immature, $(0)$ maturing $(\bullet)$ mature females

Size at first maturity $\left(L_{\mathrm{ms} 5 \%}\right)$ is conventionally defined as the length at which $50 \%$ of the individuals in a given population become sexually mature. The length distribution (ML) of squid in which gonads were

Table 3. Loligo sanpaulensis. Size at first maturity for squid from South Atlantic (Brazilian) waters

\begin{tabular}{|c|c|c|c|}
\hline Latitude & Sex & $\begin{array}{l}\text { Size range } \\
(\mathrm{ML}, \mathrm{mm})\end{array}$ & Source \\
\hline $26^{\circ} \mathrm{S}$ & Female & $75-80$ & \\
\hline $28^{\circ} \mathrm{S}$ & Female & $50-55$ & \\
\hline $30^{\circ} \mathrm{S}$ & Female & $82-97$ & \\
\hline $33^{\circ} \mathrm{S}$ & Female & $38-43$ & \\
\hline $38^{\circ} \mathrm{S}$ & Female & $75-80$ & \\
\hline $26^{\circ} \mathrm{S}$ & Male & $52-57$ & Juanico (1983) \\
\hline $28^{\circ} \mathrm{S}$ & Male & $30-35$ & \\
\hline $30^{\circ} \mathrm{S}$ & Male & $62-67$ & \\
\hline $33^{\circ} \mathrm{S}$ & Male & $23-28$ & \\
\hline $38^{\circ} \mathrm{S}$ & Male & $65-70$ & \\
\hline $\begin{array}{l}30-34^{\circ} \mathrm{S} \\
30-34^{\circ} \mathrm{S}\end{array}$ & $\begin{array}{c}\text { Female } \\
\text { Male }\end{array}$ & $\begin{array}{l}55-95 \\
60-90\end{array}$ & Andriguetto (1989) \\
\hline $\begin{array}{l}23^{\circ} \mathrm{S} \\
23^{\circ} \mathrm{S}\end{array}$ & $\begin{array}{c}\text { Female } \\
\text { Male }\end{array}$ & $\begin{array}{l}55-60 \\
50-55\end{array}$ & This study \\
\hline
\end{tabular}

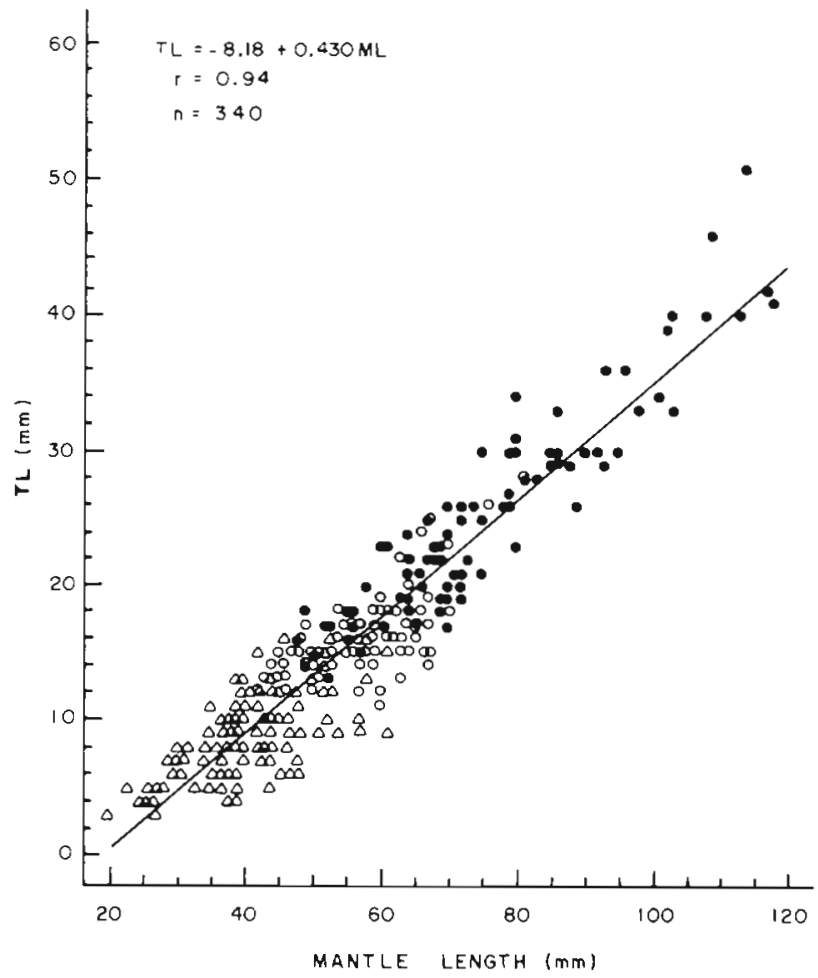

Fig. 4. Loligo sanpaulensis. Relationship between testis length and mantle length for males classified according to maturity stages. $(\Delta)$ Immature, $(0)$ maturing $(\bullet)$ mature males

observed is given in Table 2 . Based on this, the $L_{\mathrm{m} 50 \%}$ was estimated at between 55 and $60 \mathrm{~mm}$ for females and between 50 and $55 \mathrm{~mm}$ for males. Regardless of season, all male individuals $>70 \mathrm{~mm}$ and all females $>75 \mathrm{~mm}$ were mature. A comparison of $L_{\mathrm{m} 50 \%}$ values for Loligo sanpaulensis obtained in previous studies is given in Table 3.

\section{Seasonality}

Juveniles of indeterminate sex occurred up to a mantle length of $45 \mathrm{~mm}$ (mean $=26.4 \mathrm{~mm}, \mathrm{SD}=0.3$ ). Immature squid were observed throughout the year, but higher numbers of recruits followed declines in adults (Fig 5).

Data on maturity stages (males and females) of Loligo sanpaulensis from January 1987 to October 1988 were arranged by months, to show the reproductive cycle (Fig. 5). Two peaks of mature squid can be observed during the year, one in January-February and another in June-August, corresponding to summer and winter spawners respectively.

Monthly changes in the mean maturity indices (NGI, TLI) are shown in Fig. 6. There were 2 peaks in the 

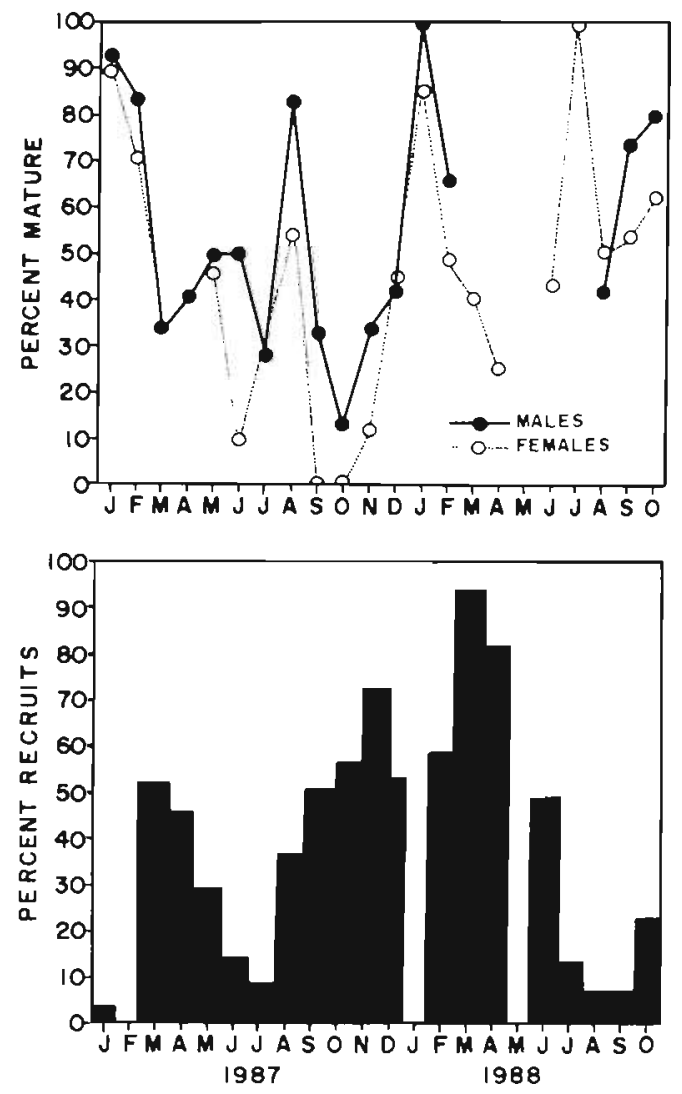

Fig. 5. Loligo sanpaulensis. Patterns of squid reproductive activity (macroscopic evaluation only) as monthly relative abundance of adults and recruits

maturity indices which occurred simultaneously in males and females, around February and August. The high maturity index values seemed to coincide with the spawning periods, as inferred from the monthly variation in the maturity stages of the gonads (Fig. 5). However, no spent females were collected during the sampling program.

\section{DISCUSSION}

The overall sex ratio did not significantly differ from $1: 1$, which is in agreement with reports on a number of other tropical-subtropical loliginids (Hixon 1980, Summers 1983). The process of maturation in Loligo sanpaulensis can be described using the development of the nidamental glands and testis as quantitative indicators of sexual maturity. Macy (1982) considered these indices to be the most reliable indicators of sexual maturity for Loligo pealei. Durward et al. (1979) have developed a 5 -stage scale for females of Illex illecebrosus. The authors showed that the relative size of the nidamental glands is well correlated with clearly defined stages in gamete development. This is a convenient classification since only 2 variables, mantle length and nidamental gland length or testis length, have to be measured. It can be used easily in largescale field studies and both indices have been widely employed (Amaratunga \& Durward 1979, Macy 1982, Okutani \& Murata 1983, Mangold 1987, Haimovici \& Perez 1990). In the present study, development of the nidamental gland and testis was strongly correlated with body size, but clearly distinct between sexes. Although males and females start to mature at the same time of year, gonad enlargement in males is a continuous process, as indicated by its linear relationship with body size, in contrast, nidamental gland development in females is slow in the small sizes and then accelerates exponentially towards the final stages.

The monthly variation in maturity indices indicated that the population undergoes 2 broad periods of maturity during the year. Despite the great variation in the data, some tendencies can be observed. The onset of maturation, indicated by the increase in mean NGI

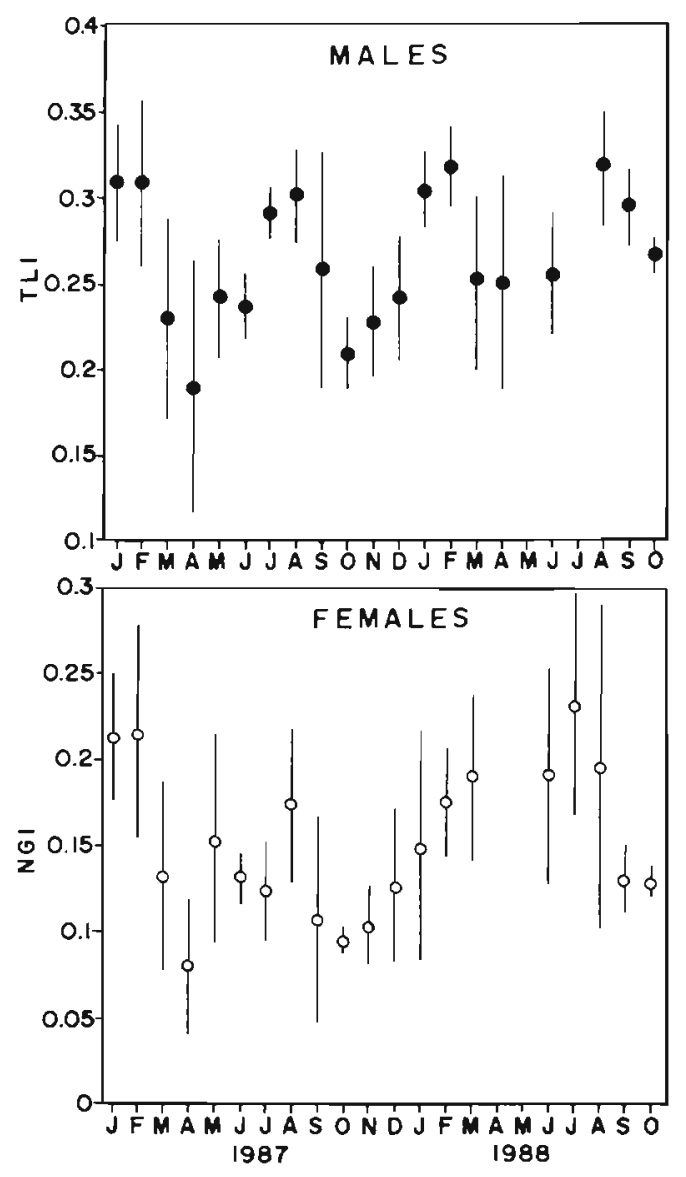

Fig. 6. Loligo sanpaulensis. Mean monthly changes in the maturity index of males (TLI) and females (NGI). Vertical lines represent the mean $95 \%$ confidence intervals 
and TLI, begins in April and October, reaching a maximum around August and February, respectively. Spawning is likely to take place in late summer and during winter. Squid at the lowest levels of maturity could be observed at all times of the year, with a tendency to follow declines in number of adults. This suggests that recruitment follows spawning, and a hypothetical post-spawn mortality or emigration of adults from the sampling area can be assumed. In fact, the absence of spent females, the presence of egg masses and the alternating seasonal occurrence of young and adults in the samples indicate that a migratory pattern may be involved in the reproductive cycle of Loligo sanpaulensis. Little information is available about migration of $L$. sanpaulensis from the time they leave the spawning grounds as hatchlings until the time they return as sexually mature adults. However, data from this species' distributional patterns in the same area reveal a low-level segregation into groups of small immature individuals inhabiting the range between 30 and $45 \mathrm{~m}$ depth during the year, while larger mature individuals occur mainly below $45 \mathrm{~m}$. Changes in the population size were strongly related to the arrival of recruits and the occurrence of a coastal upwelling mainly during spring and summer months (Costa \& Fernandes 1993). During this period, prevailing E-NE winds drive Brazil Current surface waters offshore by Ekman transport, allowing the deeper and cooler South Atlantic Central Waters to surface along the coast (Ikeda et al. 1971, Mascarenhas et al. 1971, Magliocca 1979). Currently, we have no direct evidence as to how this mechanism can affect the life cycle of L. sanpaulensis as a whole, but upwelling of cold and nutrient-rich waters results in areas of high productivity which in turn can provide feeding grounds for the juvenile squid.

Recruitment can oscillate seasonally even if spawning is continuous. The oscillating transfer functions between these processes is also known as a 'recruitment window' which opens only during certains parts of the year (Sharp 1980, Bakun et al. 1981, Pauly 1987).

Variability in spawning of Loligo sanpaulensis is very similar to that of loliginids in North America (Loligo pealei and Loligo opalescens) in which spawnings occur at different periods over their geographic distribution. The size at which maturation occurs seems to be dependent upon geographic locations and sex, as well as time of recruitment. Andriguetto (1989), studying aspects of $L$. sanpaulensis population dynamics over the continental shelf and slope in the southern areas of its distribution ( 30 to $34^{\circ} \mathrm{S}$ ), found mature squid and fertilized females year-round, but with a higher frequency during summer and winter/spring months at depths up to $100 \mathrm{~m}$, which is in agreement with our results. Andriguetto \& Haimovici (1991) found the stock concentrated in the 40 to $60 \mathrm{~m}$ zone. Large specimens with maximum mantle length averages from 63 to $88 \mathrm{~mm}$ were found between 40 and $80 \mathrm{~m}$ in all seasons. Thus, the sampling program used in this study may be considered valid for establishing the sexual cycle of the inshore population.

Our estimates of length at first maturity are well within the range of values presented by other authors. Differences could be attributed to the interactions with the environment, genetic characteristics and demographic conditions.

\section{LITERATURE CITED}

Amaratunga, T., Durward, R. D. (1979). Standardization of data collected for the short-finned squid, Mex illecebrosus. ICNAF Sel. Papers 5: 37-41

Andriguetto, J. M. F. (1989). Abundância, distribuição, hábitos alimentares e ciclo reprodutivo de Loligo sanpaulensis (Cephalopoda: Myopsida) na plataforma costeira e talude superior do Rio Grande do Sul, Brasil. M.Sc. thesis, Universidade Federal do Paraná, Curitiba

Andriguetto, J. M. F., Haimovici, M. (1991). Abundance and distribution of Loligo Sanpaulensis Brakoniecki, 1984 (Cephalopoda : Loliginidae) in southern Brazil. Sci. mar. 55(4): $611-618$

Bakun, A., Bayer, J., Pauly, D., Pope, J. G., Sharp, G. V. (1981). Ocean science in relation to living resource. Can. J. Fish. Aquat. Sci. 39(7): 1059-1070

Boyle, P. R. (1990). Cephalopod biology in the fisheries context. Fish. Res. 8: 303-321

Choe, S. (1966). On the eggs, rearing, habitats of the fry and growth of some cephalopods. Bull. mar. Sci., 16: 330-348

Cole, L. C. (1954). The population consequences of life-story phenomena. Q. Rev. Biol. 29: 103-137

Costa, P. A. S., Fernandes, F. C. (1993). Seasonal and spatial changes of cephalopods caught in the Cabo Frio (Brazil) upwelling ecosystem. Bull. mar. Sci. 52(2): $751-759$

Durward, R. D., Amaratunga, T., O'Dor, R. K. (1979). Maturation index and fecundity for female squid, Illex illecebrosus LeSuer, 1821). ICNAF Res. Bull. 14: 68-72

Hayashi, Y (1970). Studies on the maturity conditions of the common squid. I. A method of expressing maturity conditions by numeric values. Bull. Jap. Soc. scient. Fish. 36: 995-999

Haimovici, M., Perez, J. A. A. (1990). Distribucion y maduracion sexual del calamar Illex argentinus (Castellanos, 1960) (Cephalopoda: Ommastrephidae), en el sur de Brasil. Scientia mar. 54(2):179-185

Hixon, R. F. (1980). Growth, reproductive biology, distribution and abundance of three species of loliginid squid (Myopsida: Cephalopoda) in the northwest Gulf of Mexico. Ph.D. thesis, University of Miami, Coral Gables

Ikeda, Y., Miranda, L. B., Rock, N. J. (1971). Observations on stages of upwelling in the region of Cabo Frio (Brazil) as conducted by continuous surface temperature and salinity measurements. In: Proceedings of the United Nations Panel Meeting on the Establishment and Implementation of Research Programmes in Remote Sensing. Rep. 14, United Nations, New York, p. 74-97

Juanicó, M. R. (1983). Squid maturity scales for population analysis. In: Caddy, J F. (ed.) Advances in assessment of world cephalopod resources. F.A.O. Fish. Tech. Pap. 231. $341-378$ 
LaRoe, E. T. (1967). A contribution to the biology of the Loliginidae (Cephalopoda: Myopsida) of the tropical western Atlantic. M.Sc. thesis, University of Miami, Coral Gables

Macy, W. K. III (1982). Development and application of an objective method for classifying long finned squid, Loligo pealei, into sexual maturity stages. Fish. Bull. U.S. 80(3): $449-459$

Magliocca, A., Miranda, L. B., Signorine, S. S. (1979). Physical and chemical aspects of the upwelling at southwest of Cabo Frio (Lat. $23^{\circ} \mathrm{S}-$ Long. $42^{\circ} \mathrm{W}$ ). Bol. Inst. Oceanogr., São Paulo 261: 11-30

Mangold, K. M. (1987). Reproduction. In: Boyle, P. R. (ed.) Cephalopod life cycles, Vol. 2. Academic Press, London, p. $157-200$

Mascarenhas, A. S., Miranda, L. B., Rock, N. J. (1971). A study of the oceanographic conditions in the region of Cabo Frio. In: Costlow, J. D. Jr (ed). Fertility of the sea. Gordon and

This article was submitted to the editor
Breach, New York, p. 285-308

Okutani, T., Murata, M. (1983). A review of the biology of the oceanic squid Onychoteuthis borealijaponica. Mem. natl Mus. Victoria 44: 189-195

Pauly, D. (1987). A revision of the ELEFAN system for analysis of length-frequency data in fish and aquatic invertebrates. In: Pauly, D., Morgan, G. R. (eds.) Length based methods in fisheries research. ICLARM Conference Proceedings 13, Manila, and Kuwait Institute for Scientific Research, Safat, p. 7-34

Sharp, G. (1980). Report of the workshop on the effects of the environmental variation on the survival of larval pelagic fishes. Intergovernmental Oceanographic Commission Workshop Report No. 28, p. 15-59

Summers, W. C. (1983). Loligo pealei. In: Boyle, P. R. (ed.) Cephalopod life cycles, Vol. 1. Species accounts. Academic Press, London, p. 115-142

Manuscript first received: December 30, 1992

Revised version accepted: July 16, 1993 